\title{
A noção de ascensão na filosofia de Plotino
}

\author{
Bernardo Brandão \\ bgslbrandao@gmail.com \\ Universidade Federal do Paraná (UFPR), Curitiba, Brasil
}

resumo Segundo Plotino, devemos subir novamente ao Bem, que toda alma deseja (En. I, 6, 7, 1-2). De fato, descobrimos nas Enéadas algumas importantes passagens a respeito da ascensão da alma em direção ao Intelecto e o Um. Não é claro, todavia, qual a natureza dessa ascensão: Plotino escreve sobre aspectos diferentes do processo nos diversos textos. Neste artigo, tento analisar alguns desses aspectos, pensando a ascensão como despertar, orientação das faculdades da alma, interiorização e conversão.

palavras-chave Plotino; neoplatonismo; filosofia antiga; ascensão; Enéadas; epistrophé

Para compreendermos melhor o sentido da ascensão nas Enéadas, devemos antes considerar a doutrina das hipóstases. Seus traços gerais são bem conhecidos: em primeiro lugar, está o princípio supremo que, por ser a causa primeira, é chamado Bem e que, por não comportar nenhuma alteridade e ser absolutamente simples, é chamado Um. A partir dele procede o Intelecto, que é, ao mesmo tempo, a totalidade das formas inteligíveis (o tópos noetós platônico) e o intelecto (noûs) que as pensa. Em seguida, procedendo do Intelecto, está a Alma, que, sendo una e múltipla (ou seja, consistindo na hipóstase Alma, mas também na Alma do mundo e nas almas particulares), é também um ser inteligível que, no entanto, está na fronteira do imaterial, e é causa do mundo sensível, que dela procede.

Na Enéada I, 6, 6, Plotino faz um resumo dessa doutrina, pensando-a na perspectiva da beleza, que é um dos temas centrais do tratado: "em primeiro lugar, deve ser colocada a beleza, que é também o Bem; deste, 


\section{6}

vem imediatamente o Intelecto, o belo. E a Alma é bela pelo Intelecto. As outras coisas belas são formadas pela alma, nas ações e modos de vida. E os corpos, na medida em que são ditos belos, é a alma que os faz" ${ }^{1}$. Nessa passagem, percebemos a existência de uma relação causal no que diz respeito ao belo. O Um não é propriamente o belo: em I, 6, 9, tentando ser mais preciso, Plotino afirmará que ele é superior ao belo, que, de modo próprio, é o Intelecto. Por sua vez, a Alma é bela pelo Intelecto. Já os corpos, pela Alma. Mas as relações de causalidade são mais profundas. De acordo com a doutrina plotiniana, o sensível procede realmente da Alma, que procede do Intelecto, que, por sua vez, procede do Um; mas, precisamente por isso, o sensível é uma imagem menos unificada da Alma, que é imagem do Intelecto, que é imagem do Um. É por isso que podemos afirmar que a beleza sensível existe a partir da beleza da Alma: uma é imitação da outra.

De acordo com Plotino, algumas almas, não satisfeitas em governar e ordenar o universo ao lado da Alma do mundo, querendo ser de si mesmas, ou seja, buscando a individualidade e a independência, apegaram-se a corpos e acabaram por esquecer sua natureza e sua origem, apreciando mais o mundo sensível que si mesmas (V, 1, 1, 5). É assim que Plotino interpreta as afirmações platônicas a respeito da perda das asas (Fedro 246c-d) e do corpo como prisão da alma (Fédon 82e2). Algumas dessas almas se encarnaram em corpos humanos. Assim, por um lado, o homem possui um aspecto sensível por seu corpo que, iluminado por uma espécie de luz emitida pela alma (I, 1, 7, 1-5), que é chamada em algumas passagens das Enéadas de imagem da alma, forma com ela o que é chamado de composto ou de animal. Por outro lado, anterior ao composto, existe a alma que o anima. Por estar como que na fronteira do inteligível, ela, por um lado, pode ligar-se ao sensível e, por outro, não está separada do Intelecto e do Um. É nessa perspectiva que devemos entender os textos das Enéadas que falam dos dois homens, aquele que se liga ao sensível e aquele que se liga ao inteligível:

E nós (hemeîs), o que somos nós? Somos aquele ou somos o que se aproximou e surgiu no tempo? Na verdade, antes de acontecer o nascimento, estávamos lá [no inteligível], sendo outros homens e, alguns, também deuses: almas puras e intelectos unidos à essência total, partes do inteligível, sem separação, sem divisão, mas sendo do todo (e nem mesmo agora estamos separados). Mas agora, daquele homem se 
aproximou outro homem, querendo existir. E nos encontrando, pois não estávamos separados do todo, ele se revestiu de nós e acrescentou a si mesmo aquele homem, o que cada um de nós era então ${ }^{2}$.

O homem inteligível são as "almas puras e intelectos unidos à essência total", ou seja, ao Intelecto, enquanto o homem sensível é o composto animal, formado pelo corpo e pela imagem da alma. É dificil saber qual é a relação entre essas almas, puras por não estarem ligadas ao sensível, e os intelectos: é certo que, ao lado do Intelecto universal, Plotino também dá a entender que existem intelectos particulares. No entanto, ele não deixa claro no que eles consistem. Serão as formas dos indivíduos? As Enéadas também não são claras a respeito da existência de tais formas.

De qualquer modo, existe uma certa tensão entre esses dois homens: por um lado, são diferenciados: o homem inteligível vive a eternidade, enquanto o sensível surgiu no tempo; o homem inteligível está unido ao todo, enquanto o sensível, dada sua natureza corpórea, implica em certa separação; o homem inteligível não depende do homem sensível e, portanto, goza de maior autossuficiência, enquanto o homem sensível deve se revestir do homem inteligível para existir. $\mathrm{O}$ homem inteligível, por ser anterior ao sensível, é mais belo e uno que ele. Por isso, aliás, Plotino, utilizando uma expressão consagrada nos diálogos platônicos, chama-o de "homem verdadeiro" (alethés ánthropos). Tais afirmações fazem sentido se pensamos os diferentes aspectos do todo como mundos separados. No entanto, o ser humano concreto é, ao mesmo tempo, os dois homens: o homem inteligível não existe em um mundo separado do homem sensível, ainda que seja anterior a ele. Todos nós somos esses dois homens que, se parecem ser separados, é porque, em nossa vida e nossas escolhas, os percebemos assim:

Portanto, o nós é duplo: um que leva em conta a fera e outro que já está acima disso. A fera vivificada é o corpo, mas o verdadeiro homem é outro, o purificado destas coisas, que tem as virtudes da inteligência, aquelas que certamente se firmam na própria alma separada, separada e separável ainda estando aqui ${ }^{3}$.

Encontramos em nós mesmos duas tendências: uma em direção ao inteligível e outra ao sensível. Enquanto o fundamento da primeira é o homem 
verdadeiro, a base do segundo é o homem sensível, nossa natureza animal, que Plotino chama aqui de therín, termo grego que pode ser traduzido por fera ou animal selvagem, indicando que é uma parte do ser humano que está sujeita à desordem e que é rebelde às solicitações de nossa natureza superior. No decorrer de sua vida terrestre, o homem é forçado a escolher entre a tendência ao inteligível e o apego ao sensível. Essas escolhas determinam o modo de vida a ser seguido e o destino após a morte.

Não me estenderei aqui na complexa doutrina das Enéadas, sistematizada a partir de interpretações de passagens dos diálogos de Platão, das desventuras da alma após a morte e de seu ciclo de encarnações, quedas e ascensões ${ }^{4}$. De qualquer modo, de acordo com Plotino, é possível para o ser humano, ainda em vida, ligar-se novamente ao todo e ascender ao Intelecto e ao Um. No entanto, se a ascensão pode ser realizada nessa vida, na qual os dois homens necessariamente coexistem e compõem o ser humano concreto, a separação mencionada por Plotino não deve ser entendida em um sentido forte. Talvez mais adequado seja traduzir o adjetivo khoristé (separável) e o particípio khorisméne (separado) como distinguível e distinta: a alma, ainda estando aqui, não é separável do composto, já que tal separação configura a morte, mas é distinguível, ou seja, pode ser percebida em sua verdadeira natureza, a imaterial.

Em V, 9, 1, traçando um panorama da condição humana diante das realidades sensíveis e inteligíveis, Plotino fala de três espécies de homens. Em primeiro lugar, nota que "todos os homens que nascem, no princípio, utilizam o sentido antes do intelecto", síveis antes que as inteligíveis. E continua: alguns homens, dadas as necessidades materiais, "permanecendo aqui, viviam considerando essas coisas como primeiras e últimas e, assumindo que o doloroso e o agradável neles é, respectivamente, o mal e o bem, consideraram ser isso suficiente e passaram a vida perseguindo uns e fugindo de outros" ". Nesse grupo, alguns tiveram a pretensão do discurso ${ }^{7}$ e fizeram dessa experiência no mundo sensível a sua sabedoria. Assemelham-se às aves que, por causa do peso, ainda que tenham asas, não podem voar alto. Outros, "elevaram-se um pouco, movendo a parte superior da alma das coisas de baixo, do prazer para o que é mais belo"8. Mas, não podendo ver o alto, apoiaram-se, "com o lema da virtude, nas ações e escolhas das coisas de baixo" 9 . Por fim, há uma terceira espécie de homens, aqueles que alcançaram o inteligível: 
A terceira espécie, de homens divinos, com potência superior e olhos agudos, como que por agudez de observação, viu o esplendor do alto e foi elevado até lá, como que sobre as nuvens e a neblina daqui, e permaneceu lá, desprezando as coisas todas daqui e deleitando-se com o lugar que é verdadeiro e o ser que é próximo, como um homem que, após muito vagar, chega a sua pátria bem ordenada pela lei ${ }^{10}$.

Alguns comentadores acreditam que, nessa passagem (por exemplo, SZLEZAK, 2010, p. 66), Plotino estaria fazendo uma alusão às escolas filosóficas. Assim, o primeiro grupo de homens seriam os epicuristas: o segundo, os estoicos; e o terceiro, os platônicos. A suposição parece ter certo fundamento, já que Plotino, comentando o primeiro grupo de homens, fala que alguns deles tentaram fazer de sua experiência a sua sabedoria. Mas Plotino não diz mais do que isso e, portanto, é sensato pensar que o que está em jogo aqui são três modos distintos de se relacionar com as realidades sensíveis e inteligíveis que, eventualmente, podem ser formalizados nas doutrinas das escolas filosóficas. O importante aqui é a afirmação de que existe um tipo de homem que, por possuir potência superior e olhos agudos, é capaz perceber o esplendor do inteligível e, assim, ser elevado até lá e ali permanecer.

Como a Enéada V, 9 diz respeito ao inteligível, essa passagem fala de uma elevação ao Intelecto. No entanto, ele não é o fim último da ascensão. Em I, 6, 7, Plotino também fala da necessidade de se subir ao Bem, escrevendo: "devemos subir novamente ao Bem, que toda alma deseja" Existe assim, um processo de ascensão ao Intelecto e ao Bem, possível a alguns homens, aos quais exorta Plotino. Não encontramos nas Enéadas um único termo para se referir ao processo. Em V, 9, Plotino usa o verbo érthe, aoristo passivo de aíro (elevar); em I, 6, é anabatéon, um adjetivo verbal, que portanto indica necessidade, derivado do verbo anabaíno, que significa subir, ascender, elevar-se; por sua vez, em uma passagem anterior de I, 6, na qual afirma-se que a alma purificada pelas virtudes ascende ao Intelecto ${ }^{12}$, o termo empregado é anakhtheísa particípio passivo de anágo (ascender). Seguirei aqui o uso comum dos comentadores de Plotino, que privilegiam o termo anagogé, ligado a esse último verbo mencionado, anágo.

De qualquer modo, a questão central aqui é: o que significa essa anagogé? O modo mais básico de se pensar essa ascensão é considerá-la como 
um caminho de elevação ao Intelecto e, em seguida, ao Bem. Em I, 3, 1, por exemplo, Plotino emprega justamente o termo poreía, que significa o caminho seguido por alguém, mas também um processo ou um modo de caminhar ou correr, e o divide em duas partes:

O caminho é duplo para todos, um quando ascendem e o outro quando chegam ao alto. O primeiro, a partir das coisas de baixo. O segundo é para os que, tendo alcançado o inteligível e como que colocado sua pegada ali, devem viajar até chegarem aos confins do lugar, que é a meta do caminho, quando se alcança o topo do inteligível ${ }^{13}$.

A primeira parte do caminho vai do sensível ao inteligível, ou seja, alcança o Intelecto. A outra, partindo do inteligível, alcança o seu topo, que é a meta final. No início de I, 3, Plotino escreve que "para onde então é necessário ir, para o Bem e o primeiro princípio, está estabelecido e demonstrado através de vários argumentos" ${ }^{14}$. Assim, esse topo do inteligível não é outro que o Bem. Portanto, temos duas etapas: uma vai do mundo sensível ao Intelecto e a outra, do Intelecto ao Bem.

Encontramos afirmações similares em I, 6, 9: após elevar-se, a alma chegará primeiro ao Intelecto e contemplará as formas inteligíveis, que são a própria beleza. Mas, além do Intelecto, existe o Bem, que também deve ser alcançado. Do mesmo modo, em VI, 9, 11, Plotino escreve que a alma, "caindo para fora da contemplação, novamente se eleva à virtude que está em si mesma, e, percebendo que é, ela própria, ornada por elas, de novo será aliviada do peso pela virtude e se dirigirá para o Intelecto e para a sabedoria - e, pela sabedoria, até o Um"15. Ou seja, a alma que finalmente alcança a contemplação do Um, quando deixa de contemplá-lo, pode, através da virtude, dirigir-se ao Intelecto (a sabedoria é o próprio Intelecto enquanto totalidade das formas inteligíveis e sua própria intelecção) e, dali, ao Um.

Não devemos, contudo, entender literalmente as afirmações plotinianas a respeito de uma ascensão, como se indicassem uma elevação espacial. Em I, 6, 8, Plotino escreve que o caminho de ascensão e retorno à pátria querida ${ }^{16}$ não pode ser feito com os pés, carruagens ou barcos, que apenas nos conduzem pelo espaço terrestre, mas, "como que fechando os olhos, deve-se mudar para outra visão e despertá-la, aquela que todos têm, mas poucos usam"17. Trata-se, portanto, de um processo no qual se desperta 
uma outra visão que não se dirige ao sensível. Para ser mais preciso, é a atualização da natureza superior do ser humano, como que a tomada de consciência da vida do homem inteligível, que está ligado ao Intelecto e ao Um. A outra visão mencionada em I, 6 é a visão intelectual do homem verdadeiro, com a qual ele é capaz de conhecer não apenas sua natureza imaterial, enquanto alma, mas também as hipóstases superiores.

No que consiste o despertar que caracteriza a ascensão? Como podemos compreender essa atualização da vida do homem verdadeiro? Plotino não dá uma resposta definitiva e sistematizada, mas apresenta os diversos aspectos da ascensão em passagens diferentes das Enéadas. Certos textos, por exemplo, falam de uma orientação das potências da alma para o alto. Na Enéada II, 9, Plotino escreve:

Da nossa alma, uma parte está sempre voltada para coisas de lá [o inteligível], outra para as coisas daqui [o sensível] e outra está no meio delas. Já que a natureza da alma é uma e nela há muitas potências, às vezes toda ela é transportada ao mais nobre de si mesma e do ser. Outras vezes, a parte pior, arrastada para baixo, arrasta consigo o meio. Pois toda ela não é lícito arrastar. ${ }^{18}$

O texto inicia falando de partes da alma, mas logo afirma que a alma é uma, ainda que tenha várias potências. Como observou Blumenthal (1996), é o modelo aristotélico da alma una com várias faculdades que é empregado nas investigações psicológicas mais detalhadas, ainda que, em algumas análises éticas, a tripartição platônica seja usada. Assim, quando Plotino escreve que uma parte da alma está sempre voltada para o inteligível e outra para o sensível, ele parece estar pensando em potências da alma que se dirigem para cada uma dessas esferas. Em alguns momentos, a potência superior consegue levar toda a alma para o alto, enquanto, em outras ocasiões, as potências inferiores conseguem arrastar as potências intermediárias.

Em I, 1, 11, Plotino escreve que a potência superior "atua quando chega ao meio" 19 . Ainda nessa passagem, ele também afirma que nem sempre utilizamos tudo que temos, mas apenas quando "ordenamos o meio ou para o alto ou para as coisas contrárias" ${ }^{20}$. O texto de I, 1 parece dar à doutrina de Plotino uma certa simetria: podemos ordenar a parte intermediária para o alto ou para baixo, o que determinaria nosso foco de atenção. No entanto, 
essa simetria não aparece no texto de II, 9, no qual é dito que, enquanto a parte superior pode fazer com que toda a alma ascenda, as potências inferiores arrastam consigo apenas a parte intermediária.

Isso significaria que, na contemplação das hipóstases, a alma aquietaria suas potências inferiores, mas que, na sua vida sensível, ela não faria cessar sua atividade voltada ao inteligível? Essa leitura nos faz relacionar o texto de II, 9 com a doutrina da alma que não desceu ao mundo sensível, que tanta polêmica causou no neoplatonismo posterior. De acordo com Plotino, existe uma potência da alma sempre voltada para o inteligível que está sempre ativa, mesmo que não tomemos consciência dela. Em IV, 8, 8, por exemplo, ele assevera que existe uma parte da alma que não entrou no corpo, permanecendo no inteligível, que não é percebida, no entanto, quando as potências que se dirigem ao sensível dominam. Isso aconteceria porque não percebemos todas as atividades da alma, mas apenas aquelas que chegam à alma inteira:

Pois nem tudo que acontece em alguma parte da alma nós conhecemos antes que chegue à alma inteira. Assim também um desejo que permanece na faculdade apetitiva não é conhecido por nós, mas só quando o percebemos com a faculdade sensitiva interna ou com a discursiva ou com ambas ${ }^{21}$.

Não é fácil compreender o que se quer dizer com alma inteira. Poderíamos pensar que ele tem em mente apenas a parte intermediária da alma, que as potências inferiores são capazes de arrastar. No entanto, vimos que em II, 9 Plotino afirma que a influência da parte superior (ou, para ser mais preciso, da potência superior) distingue-se da influência da inferior precisamente porque a primeira é capaz de atrair toda a alma, enquanto a segunda arrasta apenas a parte intermediária. Parece-me que aqui ele talvez esteja apenas empregando uma expressão neutra, capaz de se referir às duas situações, que, como vimos, diferenciam-se no que diz respeito às partes da alma que são capazes de serem influenciadas.

Plotino é, no entanto, mais específico aqui: não temos percepção de todos os desejos de nossa faculdade apetitiva, mas apenas daqueles que captamos com a faculdade sensitiva interna, com a discursiva ou com ambas. Essa passagem é digna de nota, tanto por sua novidade, quanto por sua dificuldade. Novidade por afirmar a existência de atividades da alma 
que, de algum modo, escapam de nossa consciência, o que, nas palavras de Dodds, antecipa Leibniz quando ele afirma que existem sensações que não alcançam nossa consciência a não ser que dirijamos nossa atenção a elas, e Freud, em sua tese de que existem desejos que permanecem desconhecidos por nós $(1960$, p. 5). Dificuldade porque o texto de IV, 8 difere ligeiramente de outros textos que tratam da parte intermediária e de sua relação com nossa percepção das atividades das demais potências da alma.

Em I, 4, 10, por exemplo, Plotino afirma que existe apreensão (antílepsis) de nossos pensamentos quando eles são como que refletidos em um espelho, que formam imagens deles e que os tornam capazes de serem apreendidos. Esse espelho, por formar imagens, parece não ser outra potência que a imaginativa, a phantasía. No entanto, IV, 8 sugere que, ao menos no que diz respeito aos desejos, eles podem ser captados também exclusivamente pelo raciocínio discursivo, a diánoia. Comparando as duas passagens, devemos concluir que, enquanto os pensamentos são captados pela phantasía, os desejos podem ser captados pela phantasía, pela diánoia ou por ambos. Isso porque o pensamento captado pela phantasía é o próprio raciocínio discursivo da diánoia que, portanto, não precisa captar a si mesma, mas apenas aquilo que lhe é, de algum modo, estranho.

De qualquer maneira, parece-me que, no texto de IV, 8, Plotino está sugerindo não apenas uma, mas três possibilidades de percepção da atividade de nossas potências. A primeira é aquela que se fundamenta apenas na faculdade sensitiva comum. Essa faculdade, que parece ser, por um lado, bastante semelhante ao sentido comum aristotélico, também parece, por outro lado, quase coincidir com a phantasía, ainda que não seja preciso identificá-las totalmente. Ainda assim, penso que esse estado é aquele que existe quando imaginamos alguma coisa sem processá-la racionalmente. Trata-se de uma disposição próxima à dos animais, que não possuem raciocínio discursivo.

A segunda possibilidade é a mais comum e tipicamente humana. É o estado que utiliza tanto a phantasía quanto a diánoia: a percepção que existe quando temos uma imagem de algum pensamento, emoção ou sensação e, ao mesmo tempo, também temos uma certa compreensão racional. É o nosso pensamento a partir de imagens. Mas, por fim, existe uma terceira possibilidade, que é a percepção realizada somente a partir da diánoia. Estamos aqui diante de uma espécie de consciência ${ }^{22}$ sem 


\section{4}

imagens, fundamentada exclusivamente na parte dianoética da alma. Minha hipótese é que esse pode ser o estado que, para ser distinguido dos demais estados mentais, foi chamado por Smith (1978) de quase-consciência. É a disposição típica das ações mais elevadas, que requerem um nível maior de concentração. Plotino as descreve na continuação da já citada passagem de I, 4, 10:

Alguém encontraria muitas belas atividades, tanto contemplações quanto ações, também quando estamos despertos, das quais não temos a consciência. Pois não é necessário a quem está lendo ter consciência de estar lendo, sobretudo quando lê com intensidade; nem quem é corajoso, de estar sendo corajoso e de agir, na medida em que age, conforme a coragem. E outros milhares de exemplos; é que as tomadas de consciência podem fazer mais débeis as próprias atividades de que tomam consciência, enquanto, estando elas sós, são então puras e agem mais e vivem mais e, certamente, estando o sábio nesse estado, o viver é mais intenso, pois não está difuso na sensação, mas está reunido naquilo que é seu em si mesmo ${ }^{23}$.

A consciência sem imagens é a mais comum durante as ações virtuosas. Como Plotino observa, nesses casos a autoconsciência da própria performance, que me parece se fundamentar em uma imagem da atividade, seria um obstáculo para a sua execução. Assim, ao contrário da inconsciência, que é um estado de desagregação provocado por algum distúrbio físico, esse parece ser um estado superior ao da consciência ligada à imaginação. Tendo isso em mente, podemos compreender melhor o texto de II, 9. Quando a atividade das potências inferiores chega até as intermediárias, tomamos consciência delas e, assim, deixamos de perceber a parte superior, que, no entanto, continua ativa. É por isso que se pode dizer que a parte inferior da alma arrasta a intermediária, mas não a superior.

No entanto, não fica claro como a parte superior pode elevar toda a alma. A partir da noção de uma consciência sem imagens, seria possível pensar na inatividade da parte intermediária, se a pensarmos como se constituindo apenas da phantasía e de potências que operam a partir dela, como a memória. Mas como pensar na inatividade de nossas potências sensitivas e vegetativas? Acaso isso seria o equivalente a dizer que, durante os momentos em que a alma toda ascende, as atividades corpóreas 
cessariam? Que a elevação da alma ao inteligível equivaleria a um arroubo místico que paralisaria as atividades do corpo? Por outro lado, afirmar que, quando a parte superior eleva a alma, o que ocorre é apenas um direcionamento do foco de atenção para o alto, enquanto as partes inferiores da alma ainda estariam ativas, tornaria dificil entender como Plotino pôde afirmar que, enquanto a parte inferior arrasta a intermediária, a superior eleva toda a alma.

Talvez essa falta de simetria seja fruto da doutrina da imagem da alma: para Plotino, as atividades corpóreas não são responsabilidade direta da alma, mas são reguladas por sua imagem. Poderíamos assim pensar na elevação da alma como uma certa separação momentânea dessa imagem que regula o corpo. Em V, 1, 10, Plotino escreve:

A exortação de se separar não é dita de um lugar - pois a alma já é separada por natureza - mas do não consentir com as imagens e com a alteridade que estão junto ao corpo, bem como de reunir e levar para o alto a parte restante da alma, aquela que se assenta aqui, que é o único artífice do corpo e que tem a capacidade de esculpi-lo e se ocupar com ele $\mathrm{e}^{24}$.

Quando Plotino fala em não consentir com as imagens e a alteridade que estão juntas ao corpo, ele parece justamente indicar a inatividade da faculdade imaginativa. Por sua vez, quando fala da elevação de certa parte da alma, aquela que é artífice e se ocupa do corpo, ele deve ter em mente ou a imagem da alma ou a potência vegetativa da qual essa imagem procede. Como o texto fala de uma parte, não de uma imagem, e de artífice do corpo, sou levado a lê-lo como tratando da potência vegetativa. Nessa leitura, tal potência deveria ser reunida (o verbo é o aoristo de sumphéro, que indica levar junto, coletar) provavelmente com as partes restantes da alma e, juntamente com elas, levada ao alto, ou seja, orientada para os princípios superiores. Plotino não especifica em que consistiria essa elevação, mas é possível entendê-la justamente como uma separação da imagem da alma.

De qualquer modo, a ascensão, assim, poderia ser pensada, ao menos em seus estágios iniciais, como a tomada de consciência da atividade da parte superior da alma que seria realizada através de uma espécie orientação das potências da alma ao alto, orientação essa entendida, talvez, como a inatividade da phantasía e a não recepção das afecções provenientes do 


\section{6}

composto animal. Nesse sentido, o despertar da visão interior significaria uma certa disposição das faculdades da alma.

Mas não podemos pensar que a alma se dirija, nessa orientação ao alto, para algo exterior. Em V, 1, Plotino afirma que, assim como as hipóstases existem na natureza, também existem no homem, ou, para ser mais preciso, no homem interior ${ }^{25}$ : em primeiro lugar, encontramos a alma, que, ainda que não seja todo o homem, é o eu verdadeiro e real. Mas a atividade fundamental da alma humana é a diánoia, o raciocínio que se realiza discursivamente e que depende de certos princípios intelectuais. Assim, se, por exemplo, a alma raciocina sobre ações justas e nobres é necessário existir o justo que fundamenta o raciocínio ${ }^{26}$. E, se o raciocínio da alma fundamenta-se nas formas inteligíveis e se temos acesso a elas, elas devem ser pensadas como estando em nós. Como a totalidade das formas inteligíveis constitui o Intelecto, "é preciso que exista em nós um Intelecto que não raciocine, mas tenha sempre o justo" 27 . Por sua vez, é necessário uma causa do Intelecto, que é o deus ${ }^{28}$, ou seja, o Um.

Não devemos entender a afirmação de que o Intelecto e o Um estão em nós como uma afirmação panteísta. Em I, 1, 8, 3-10, afirma-se que possuímos o Intelecto como que por cima de nós e o Um, acima da natureza inteligível. Como nas Enéadas as expressões que indicam superioridade devem ser compreendidas como afirmações de anterioridade e causalidade, nessa passagem Plotino afirma não que o Intelecto e o Um façam parte da alma como um elemento faz parte de um composto, mas que possuímos o Intelecto enquanto ele é fundamento da alma humana e que possuímos o Um enquanto ele é causa do Intelecto.

Portanto, assim como no caso das expressões que indicam superioridade, também não devemos entender a afirmação de que o Intelecto e o Um estão em nós espacialmente. Enquanto se fala em superioridade para significar excelência, fala-se em interioridade para indicar que os princípios são como que pressupostos da existência e das atividades da alma. Eles não podem ser conhecidos como objetos de conhecimento porque são o próprio fundamento desse conhecimento, ou seja, estão presentes em todo ato cognoscitivo da alma ${ }^{29}$ : o Intelecto, enquanto a própria realidade inteligível da qual depende todo raciocínio discursivo, e o Um, enquanto princípio da unidade presente em todos os seres, inteligíveis ou sensíveis. Em V, 3, Plotino apresenta um outro aspecto da doutrina: 
Não dizemos que (o Intelecto) é da alma, mas dizemos que é nosso intelecto. Sendo diferente da parte discursiva e estando situado acima desta, contudo é nosso, mesmo se não o contarmos entre as partes da alma. Ou melhor, é nosso e não é nosso. Por isso nos valemos dele e não nos valemos, mas da razão discursiva valemo-nos sempre. É nosso quando o usamos e, quando não o usamos, não é nosso. ${ }^{30}$

Se é possível asseverar que possuímos sempre o Intelecto por dependermos dele, no entanto, também podemos dizer, como Plotino faz em V, 3, que ele é nosso quando o usamos e, quando não o usamos, que ele não é nosso. Afirmações aparentemente divergentes que não me parecem, entretanto, se contradizer. Por um lado, sempre o possuímos enquanto nosso ser depende dele. Por outro, nem sempre o possuímos, pois nem sempre temos conhecimento dele. É precisamente nesse hiato que se situa a ascensão, que, portanto, pode ser também entendida como um caminho de autoconhecimento.

Esse é o tema de V, 1, 12: após apresentar a doutrina da existência dos princípios em nós em V,1,11, Plotino se pergunta: "como então, possuindo tão grandes coisas, não as percebemos, mas nos desocupamos de tais operações na maioria das vezes, sendo que alguns nunca as operam?". ${ }^{31}$ Aqui são retomadas as ideias de IV, 8: "pois nem tudo que está na alma é perceptível, mas vem até nós quando chega à sensação"32.

Quando uma atividade de uma potência da alma não chega à faculdade sensitiva, "ainda não atravessou a alma inteira" 33 e, assim, não a percebemos: "ainda não a conhecemos, já que estamos junto do sensível e não somos parte da alma, mas toda a alma" 34 . Na sua condição atual, encarnada em um corpo, a alma não é capaz de se voltar totalmente para os aspectos anteriores da realidade, pois situa-se entre o sensível e o inteligível. Assim, para perceber a presença das hipóstases, é necessário "converter a percepção para dentro e ali fazê-lo ter atenção" 35. A ascensão é pensada nessa passagem como uma interiorização, como o ato de converter a percepção para dentro e ali dispor sua atenção. Plotino emprega aqui dois termos importantes: epistréphein e prosokhé, que traduzo, respectivamente, por conversão e atenção.

Como observa Hadot (1968, p. 979), a palavra latina conversio corresponde a duas palavras gregas, epistrophé, que implica a ideia de um retorno 
à origem ou ao $e u$, e metánoia, que indica arrependimento e mudança de mentalidade. Ambas foram utilizadas nos textos da filosofia e do cristianismo. Nas suas palavras:

A filosofia antiga nunca foi a construção de um sistema abstrato, mas aparece como um apelo à conversão através da qual um ser humano recupera sua natureza original (epistrophé) em um desenraizamento da perversão na qual os mortais comuns vivem, e em uma reorientação drástica de todo o seu ser (metánoia).

A palavra metánoia aparece nas Enéadas, em II, 1, 4 e II, 9, 6, de uma forma pejorativa, como um termo técnico usado no gnosticismo para falar do arrependimento da alma: de acordo com Plotino, os gnósticos plasmam esses termos como se não tivessem contato com a antiga língua grega (II, $9,6)$. No entanto, a palavra epistrophé, substantivo da mesma raiz do verbo epistrépho, apesar de ser usada em uma variedade de contextos, aparece em algumas passagens indicando a conversão da alma do filósofo ao inteligível. Para ser mais preciso, nas Enéadas, a conversão à filosofia ganha novas conotações, o que é justamente o que a passagem aqui em questão indica: para Plotino, a conversão à filosofia é, antes de tudo, o retorno da alma às realidades superiores e interiores que a fundamentam.

Por sua vez, também de acordo com Hadot, a prosokhé é uma prática de atenção à própria alma e uma renovação, a cada instante, da escolha de vida, consciência de si e desapego do que é supérfluo. Em suas palavras, "é necessário que o filósofo seja, a cada instante, perfeitamente consciente do que é e do que faz" (2008, p. 277). Empregada por estoicos e platônicos, também aparecerá no cristianismo. Encontramos uma menção a essa prática, por exemplo, em Clemente de Alexandria: “é necessário que a lei divina inspire o temor, a fim de que o filósofo adquira e conserve a tranquilidade da alma, graças à prudência e à atenção (prosokhé) consigo mesmo" (Stromata II, 20, 1).

$\mathrm{Na}$ passagem de $\mathrm{V}, 1$, aqui em questão, percebemos que também esse termo adquire conotações mais específicas. Não me parece tanto indicar uma tomada de consciência de suas próprias ações, para que sejam isentas de erro, tal como em Clemente, mas o direcionamento da atenção para as realidades superiores. $\mathrm{Na}$ continuação do texto, Plotino compara esse direcionamento ao de alguém que, esperando escutar a voz que deseja, 
afasta o ouvido dos outros sons e desperta para a melhor das coisas que pode ouvir até que aquela apareça. Assim também, ele conclui, é preciso se afastar das audições sensíveis, "guardar pura a parte perceptível da alma e nos prepararmos para ouvir os sons do alto" 36. A acepção de prosokhé que está em jogo aqui é a de uma atenção que, deslocando-se do sensível, dirige-se para o inteligível e o Um.

Mas as noções de despertar, orientação das potências da alma, interiorização e conversão não são suficientes para explicar a ascensão. Nenhuma dessas noções é capaz de abarcar a natureza da contemplação das hipóstases, que parece estar rodeada de aporias. É que, se, por um lado, ela aparece como uma atividade da alma, ou melhor, como sua atividade superior, em alguns textos, ela aparece como quietude e abertura para as realidades superiores, ou seja, como um estado de passividade.

Assim, lemos em I, 3, 4 que, após a prática da dialética, a alma, “então, aquietando-se, pois, enquanto está lá, está em quietude, e não mais estando curiosa, tornando-se una, vê" ${ }^{37}$. Ou seja, fala de repouso e unidade. Mas como repousar em uma atividade intensa?

Já emV,1,3, Plotino afirma que, quando a alma contempla o Intelecto, "tem dentro de si, como próprios, as coisas que pensa e atualiza" 38 e, do mesmo modo, que a alma é aquela que recebe, enquanto o Intelecto é como a forma ${ }^{39}$ que informará a alma. Ou seja, a contemplação do Intelecto pela alma aparece como um estado de passividade e receptividade de uma forma, não como uma atividade. Como, pois, uma atividade pode, ao mesmo tempo, ser descrita como tal estado de receptividade?

Por outro lado, o Intelecto e o Um não podem ser objetos de conhecimento como um corpo sensível pode ser objeto de visão. Conhecer um ser sensível é perceber as qualidades sensíveis inerentes a outra substância e, a partir daí, conhecer de algum modo essa substância, mas como outra. Mas, como foi discutido, as realidades superiores, ainda que não sejam um elemento constituinte da alma, também não são meramente uma substância diversa, mas o próprio fundamento da existência da alma e de seu conhecimento. Não podem ser, portanto, conhecido como um objeto, mas apenas como o fundamento do conhecimento. A apresentação da ascensão como um processo de interiorização nos orienta nessa direção e mostra que as hipóstases não são objetos de conhecimento como objetos exteriores o podem ser. No entanto, não explica como essa visão é 
realizada: ver o que está em nós é como ver o que está dentro de uma substância sensível? Como se trata de uma interioridade metafísica, obviamente, esse não pode ser o caso. Como compreender então essa visão? A solução para esses problemas parece estar nas passagens das Enéadas que falam do conhecimento das hipóstases como uma união. Nessa perspectiva, levar a alma inteira para o alto seria uni-la com o Intelecto e o Um. Ou seja: a ascensão seria o processo pelo qual a alma se tornaria capaz de se unir ao Intelecto e, em seguida, ao $\mathrm{Um}^{40}$.

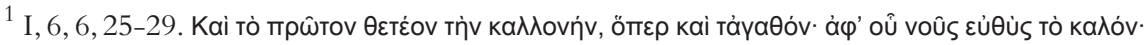

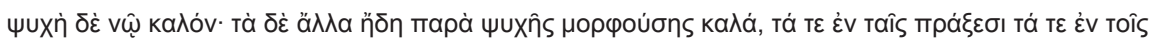

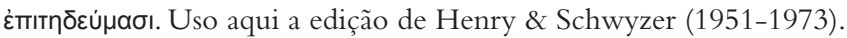

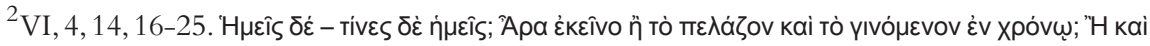

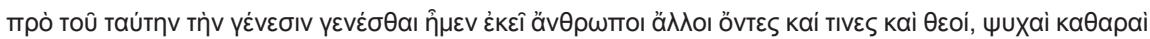

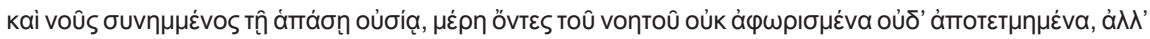

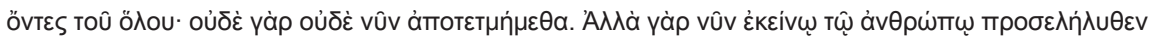

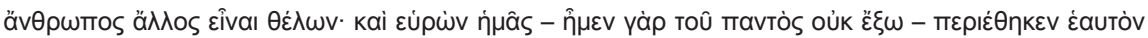

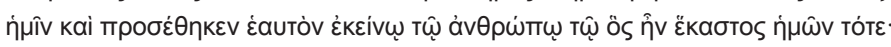

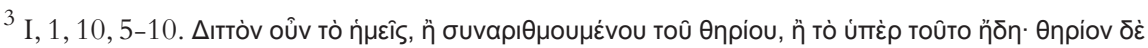

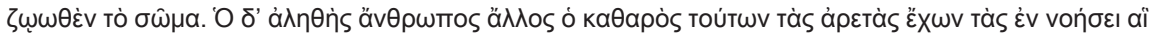

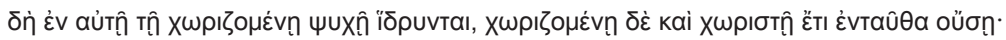

${ }^{4}$ Cf. BUSSANICH, 2010.

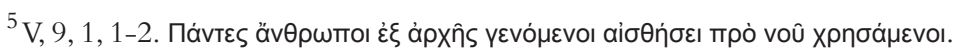

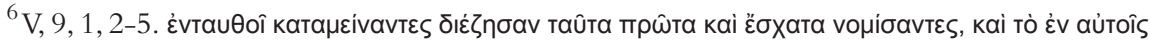

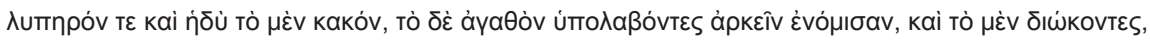

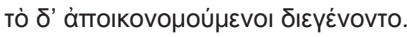

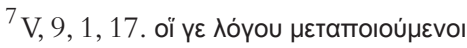

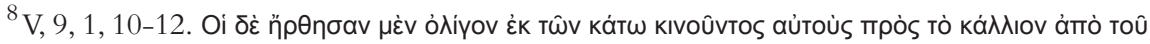

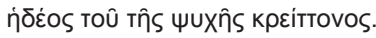

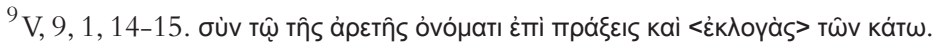

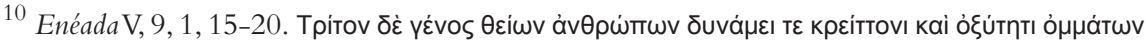

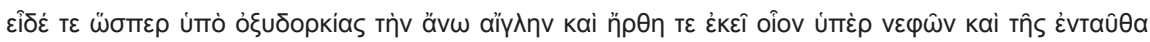

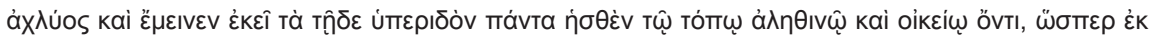

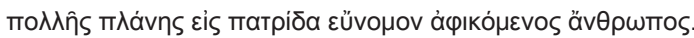

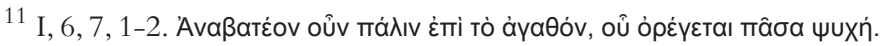




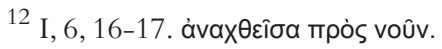

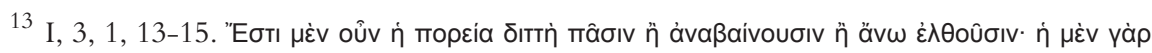

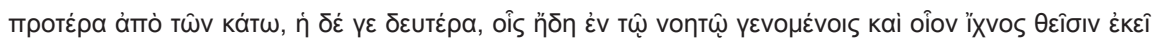

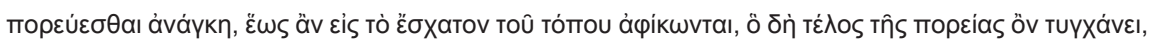

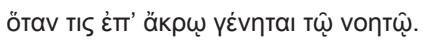

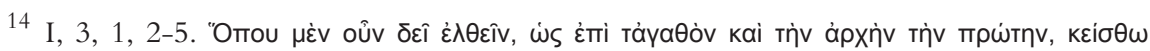

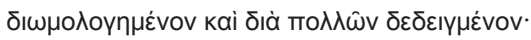

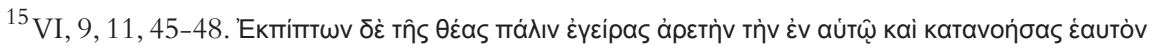

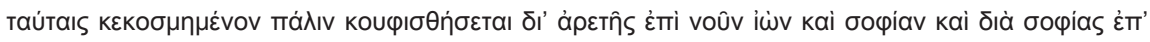
aủió.

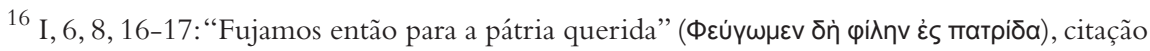
da Ilíada, 2, 140 .

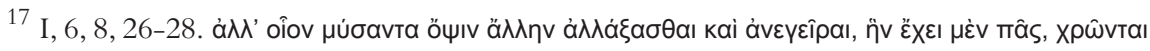

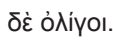

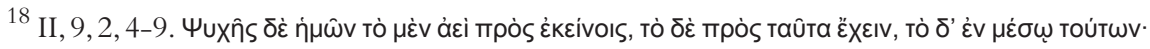

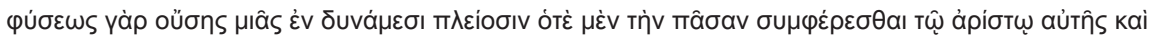

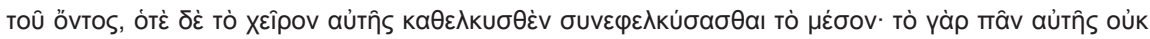

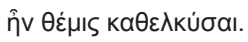

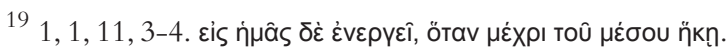

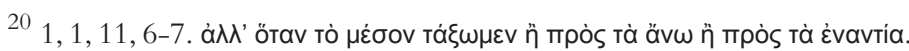

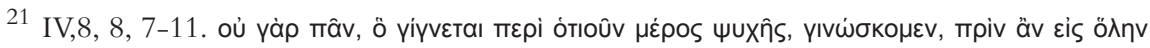

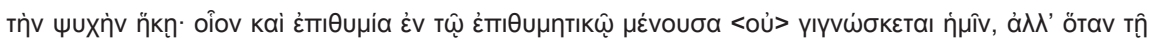

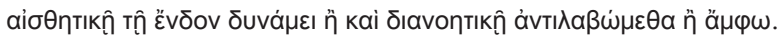

22 É certo que temos que tomar cuidado ao falar de consciência em Plotino, dadas todas as conotações pós-cartesianas do termo, tal como compreendido nos dias de hoje. Contudo, como ele é largamente utilizado pelos estudiosos contemporâneos das Enéadas, também o empregaremos, não deixando de notar, entretanto, que seu sentido é ligeiramente diferente do atual. Além disso, Plotino utilizava três palavras distintas para se referir àquilo que os estudiosos chamam de consciência: antílepsis, parakoloúthesis e sunaísthesis. É, aliás, por isso mesmo que podemos utilizar o termo como uma palavra genérica que, nos diversos contextos, pede certas especificações.

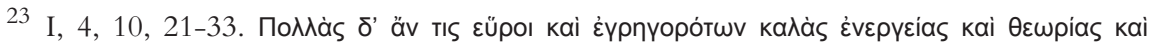

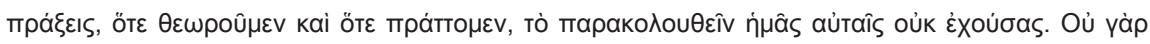

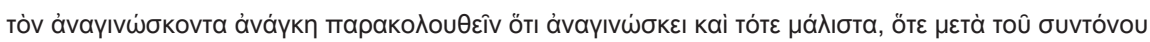

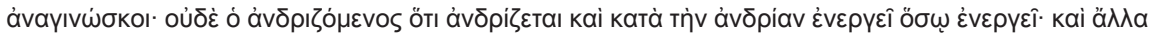

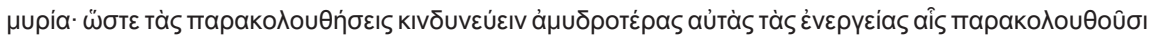

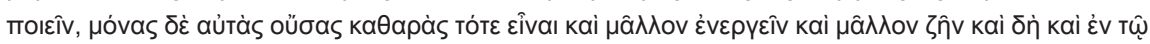

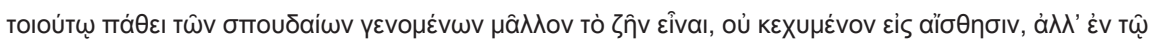

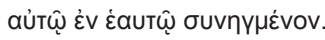

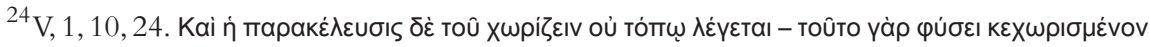




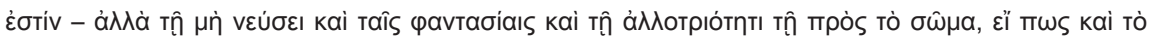

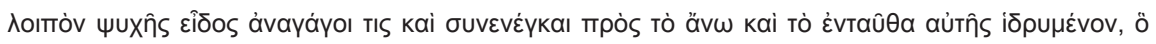

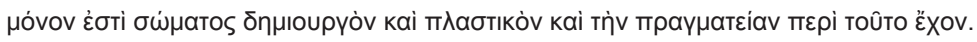

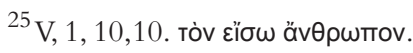

${ }^{26} \mathrm{~V}, 1,11,1-5$.

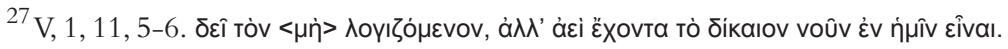

${ }^{28} \mathrm{~V}, 1,11,7-8$.

${ }^{29}$ As palavras de Moevs $(2005$, p. 5) a respeito da metafisica de Dante, que ele interpreta em termos neoplatônicos, são oportunas aqui: "Deus, sujeito último de toda experiência, não pode ser conhecido como objeto de experiência: conhecer Deus é se conhecer como Deus".

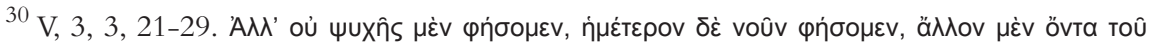

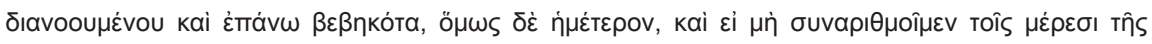

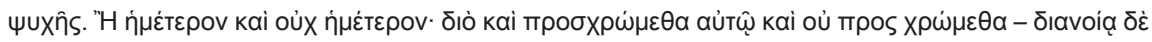

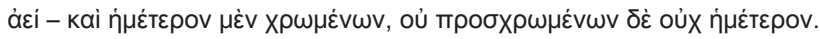

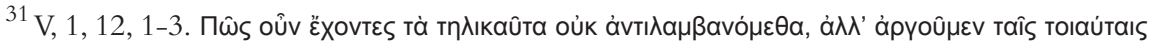

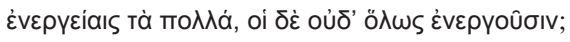

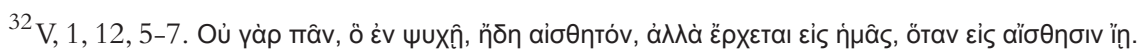

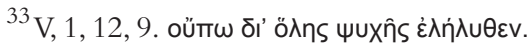

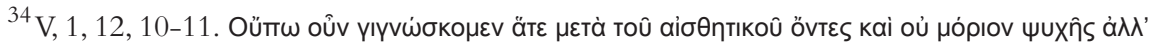

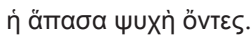

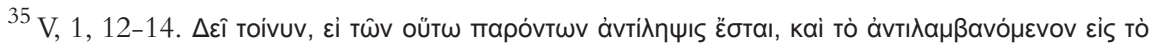

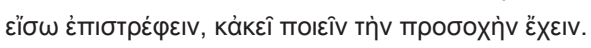

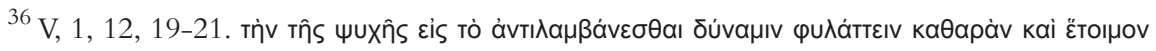

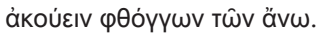

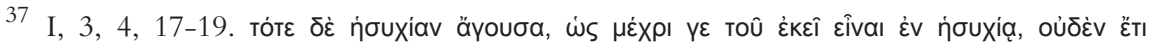

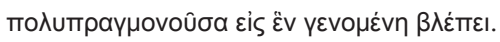

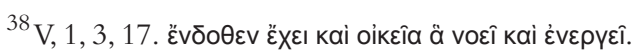

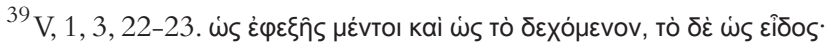

${ }^{40}$ Sobre o problema da união da alma com o Intelecto, cf. BRANDÃO, 2007. A respeito da união da alma com o Um, cf. BRANDÃO, 2009.

\section{Referências bibliográficas}

BLUMENTHAL, H. 1996. On Soul and Intellect. In: GERSON, L.

The Cambridge Companion to Plotinus. Cambridge: Cambridge University

Press, p. 82-104. 
BRANDÃO, B. 2009. A união da alma com o Um na filosofia de Plotino. Síntese, n. 114, p. 87-105. Resumo disponível em http://www. faje.edu.br/periodicos/index.php/Sintese/article/viewArticle/96 2007. A união da alma e do Intelecto na Filosofia de

Plotino. Kriterion, n. 116, p. 481-491. Disponível em http://www.scielo. br/pdf/kr/v48n116/a1348116.pdf

BUSSANICH, J. 2010. The Ethicization of Rebirth Eschatology in Plato and Plotinus. In: ADLURI,Vishwa. Greek Religion: philosophy and salvation. Berlim: De Gruyter.

DECK, J. 1991, Nature, contemplation and the One: a study in the philosophy of Plotinus. Burdett: Larson Publications.

DODDS, E. 1960. Tradition and personal achievement in the philosophy of Plotinus. Journal of Roman Studies, 50, p. 1-7.

HADOT, P. 1968. Conversion. Encyclopaedia Universalis, vol. 4. Paris: Encyclopaedia Universalis France, p. 979-981. 2008. O Que é filosofia antiga? São Paulo: Loyola.

HENRY, P. \& SCHWYZER, H. 1951-1973. Plotini opera (3 vols). Leiden: Brill.

IGAL, J. 1979. Aristotele y la evolución de la antropologia de Plotino. Pensiamento 35, p. 315-346.

LLOYD, G. 1994. Plotinus. Nova York: Routledge.

MARQUES, M. 2011. Contra a teoria de dois mundos na filosofia de Platão. RepúblicaV 476E-478E. In: CONTE, J.; BAUCHWITZ, O. (Org.). O que é metafísica? Atas do III Colóquio Internacional de Metafísica. Natal, RN: EDUFRN, p. 245-260.

MOEVS, C. 2005. The Metaphysics of Dante's Comedy. Oxford: Oxford University Press.

O'MEARA, D. 1996. The Hierarchical Ordering of Reality in Plotinus. In: GERSON, L. The Cambridge Companion to Plotinus. Cambridge: Cambridge University Press. 
74

SMITH, A. 1978. Unconsciousness and quasiconsciousness in Plotinus. Phronesis, 23, p. 292-301.

SZLÉZAK, T. 2010. Platão e Aristóteles na doutrina do Noûs de Plotino. S. Paulo: Paulus. 